\title{
EKSISTENSI FILSAFAT HUKUM ISLAM DALAM PENGEMBANGAN EKONOMI ISLAM INDONESIA
}

\author{
${ }^{1}$ SISKA LIS SULISTIANI \\ ${ }^{1}$ Fakultas Syariah Universitas Islam Bandung, Jl.Ranggagading No.8 Bandung 40116 \\ Email: siscaassidq@yahoo.co.id
}

\begin{abstract}
Abstrak : Ekonomi islam saat ini menjadi sistem ekonomi yang banyak diminati bahkan oleh negara-negara maju sekalipun, yang membedakan dengan sistem ekonomi lainnya salah satunya adalah sumber hukum yang mendasari segala aktifitas ekonomi, dan dasar-dasar filosofis hukum islam lainnya yang menjadi landasan dalam pengembangan ekonomi Islam dimanapun dan dalam bentuk apapun, serta tidak boleh keluar dari koridor syariah. Kemaslahatan merupakan tujuan utama dalam aktifitas ekonomi Islam dan menjauhi semua bentuk kemadharatan. Melalui tulisan ini dengan metode penelitian kualitatif, dengan pendekatan yuridis normatif melalui studi kepustakaan. Sehingga dengan metode tersebut dapat digali nilai-nilai filosifis dalam pengembangan ekonomi islam di Indonesia.
\end{abstract}

Kata Kunci: Ekonomi, islam, filsafat, hukum.

Abstract : Islamic economics today is an economic system that is in great demand by developed countries, which distinguishes it from other economic systems One of them is the source of law underlying all economic activities, and the philosophical foundations of other Islamic laws which are the foundation in the development of Islamic economics everywhere and in any form, and should not leave the sharia corridor. Welfare is the main objective in Islamic economic activity and away from all forms of kemadaaratan. Through this paper with the method of qualitative study, with normative juridical approach through literature study. With this method can be explored the philosophical values in the development of Islamic economics in Indonesia.

Keywords: Economic,Islam,philosof, dan law.

\section{PENDAHULUAN}

Islam adalah agama yang universal dan komprehensif. Universal berarti bahwa Islam diperuntukkan bagi seluruh ummat manusia di muka bumi dan dapat diterapkan dalam setiap waktu dan tempat sampai akhir zaman. Komprehensif artinya bahwa Islam mempunyai ajaran yang lengkap dan sempurna (syumul). Kesempurnaan ajaran Islam, dikarenakan Islam mengatur seluruh aspek kehidupan manusia, tidak saja aspek spiritual (ibadah murni), tetapi juga aspek mu'amalah yang meliputi ekonomi, sosial, politik, hukum, dan sebagainya. Sebagai ajaran yang komprehensif, Islam meliputi tiga pokok ajaran, yaitu aqidah, syari'ah dan akhlak. Hubungan antar aqidah, syari'ah dan akhlak dalam sistem Islam terjalin sedemikian rupa sehingga merupakan sebuah sistem yang komprehensif. Syariah Islam terbagi kepada dua yaitu ibadah dan mu'amalah. Ibadah diperlukan untuk 
menjaga ketaatan dan keharmonisan hubungan manusia dengan khaliq-Nya. Mu'amalah dalam pengertian umum dipahami sebagai aturan mengenai hubungan antar manusia.

Salah satu aspek penting yang terkait dengan hubungan antar manusia adalah ekonomi. Ajaran Islam tentang ekonomi memiliki prinsip-prinsip yang bersumber Al-Quran dan Hadits. Prinsipprinsip umum tersebut bersifat abadi, seperti prinsip tauhid, adil, maslahat, kebebasan dan tangung jawab, persaudaraan, dan sebagainya. Prinsipprinsip ini menjadi landasan kegiatan ekonomi di dalam Islam yang secara teknis operasional selalu berkembang dan dapat berubah sesuai dengan perkembanga zaman dan peradaban yang dihadapi manusia. Oleh karena itu pentingnya mengetahui filsafat hukum ekonomi islam yang dalam hal ini untuk mengembangkan ekonomi islam yang akan dibahas dalam tulisan ini.

Penelitian ini merupakan penelitian kualitatif, yang dipergunakan dalam penelitian ini adalah studi kepustakaan (library research) yaitu jenis penelitian kualitatif yang data-datanya diperoleh dari buku, kitab, majalah, surat kabar, jurnal dan catatan lainnya yang memiliki relevansi dengan permasalahan yang akan dibahas.
Saat pengumpulan data, untuk mempermudah dalam pembuatan tulisan ini dan mendapat kesimpulan yang tepat, dalam pengumpulan data penulis menggunakan metode dokumenter yaitu mencari data mengenai hal-hal atau variabel yang berupa tulisan-tulisan, bukubuku, artikel-artikel yang relevan dengan tema penulisan ini.

Pada penelitian ini, pengolahan data hanya ditujukan pada analisis data secara deskriptif kualitatif, di mana materi atau bahan-bahan tersebut untuk selanjutnya akan dipelajari dan dianalisis muatannya, sehingga dapat diketahui taraf sikronisasinya, kelayakan norma, dan pengajuan gagasan-gagasan normatif baru. Kualitatif dimaksudkan yaitu analisis yang bertitik tolak pada usaha penemuan asas dari informasi yang bersifat monografis dan responden, memahami kebenaran yang diperoleh dari hasil pengamatan dan pertanyaan kepada sejumlah responden baik secara lisan maupun tertulis selama dalam melakukan kegiatan penelitian.

\section{PEMBAHASAN}

\section{A. Pengertian Filsafat}

Filsafat berasal dari kata Yunani, yaitu philosophia, gabungan antara philein yang berarti mencintai, dan sophia berarti kebijaksanaan. Orang yang berfilsafat atau orang yang melakukan filsafat disebut 
SIska Lis Sulistiani : Eksistensi Filsafat Hukum Islam..

filsuf atau filosof artinya pencinta kebijaksanaan(Hasyimsyah Nasution, 2002). Selain itu, dalam bahasa Arab dikenal kata hikmah yang hampir sama dengan arti kebijaksanaan, kata hikmah atau hakiem dalam bahasa Arab dipakai dalam pengertian falsafah dan failasuf, namun tidak semua kata hikmah atau hakiem dapat diartikan falsah atau filsuf. (Zainuddin Ali, 2006)

Menurut Filsuf Yunani Plato ( 427347 SM) yang pendapat bahwa, filsafat itu adalah pengetahuan tentang segala yang ada(Endang Saiffudin Anshari, 1981). Adapun Istilah filsafat pertama kali dikenalkan oleh Pythagoras (497 SM) istilah ini dipakai oleh Pythagoras sebagai reaksi terhadap orang-orang cendikiawan pada masanya yang menamakan dirinya sebagai “ahli pengetahuan”( Hanafi Ahmad, 1996). Selain itu, Filsuf Heroklaitos (540480 SM) sudah memakai kata falsafat untuk menerangkan hanya tuhan yang mengetahui hikmah dan pemilik hikmah, manusia harus puas dengan tugasnya di dunia sebagai pencari dan pencipta hikmah. (Clement, C.J. Webb, 1949)

Definisi filsafat secara terminologi memiliki berbagai macam pengertian. Para filsuf mendefinisikan sesuai dengan latarbelakang pemikiran kefilsafatan yang dimilikinya, seperti : Socrates (469 - 399

EISSN:2540-8402 | ISSN : 2540-8399
SM) : filsafat adalah suatu peninjauan diri yang bersifat reflektif atau perenungan terhadap asas-asas dari kehidupan yang adil dan bahagia (principles of the just and happy).Plato ( 428 -348 SM ) : filsafat merupakan pencarian yang bersifat spekulatif atau perekaan terhadap pandangan tentang kebenaran (Gie Liang)

Maka filsafat tidak didalami dengan melakukan eksperimen-eksperimen dan percobaan-percobaan, tetapi dengan mengutarakan masalah secara persis, mencari solusi untuk itu, memberikan argumentasi dan alasan yang tepat untuk solusi tertentu. Akhir dari proses-proses itu dimasukkan ke dalam sebuah proses dialektika. Untuk studi falsafi, mutlak diperlukan logika berpikir dan logika bahasa. Sehingga dapat disimpulkan bahwa filsafat adalah studi tentang seluruh fenomena kehidupan dan pemikiran manusia secara kritis dan dijabarkan dalam konsep mendasar. (http://id.wikipedia.org/wiki/Filsafat. diakses 10 April 2012. 20.59pm)

\section{B. Pengertian Hukum Mu'amalah dan Ekonomi Islam}

Hukum mu'amalah merupakan rangkaian dari kata "hukum" dan kata “mu'amalah". Kedua itu secara terpisah, merupakan kata yang digunakan dalam bahasa Arab dan terdapat dalam AlQur'an, juga berlaku dalam bahasa 
Indonesia. " hukum mu'amalah" sebagai suatu rangkaian kata telah menjadi bahasa Indonesia yang hidup dan terpakai. Dalam bahasa Indonesia kata 'hukum' secara mandiri menurut Amir Syarifuddin adalah seperangkat peraturan tentang tingkah laku manusia yang diakui sekelompok masyarakat, disusun orang-orang yang diberi wewenang oleh masyarakat itu, berlaku dan mengikat untuk seluruh anggotanya. (Amir Syarifuddin, 2011)

Adapun mu'amalah dari kata 'amala yu'amilu mu'amalatan yang berarti: beraksi, bekerja, berproduksi, namun biasanya dengan kaitan hukumnya kata "mu'amalah" di sandingkan dengan kata "fiqh" yang secara bahasa berarti “ pemahaman". (Ali Athabik, 1996)

Adapun pengertian ekonomi islam yang terdiri dari dua kata ekonomi dan islam. Ekonomi merupakan salah satu ilmu sosial yang mempelajari aktivitas manusia yang berhubungan dengan produksi, distribusi, dan konsumsi terhadap barang dan jasa. Istilah "ekonomi" sendiri berasal dari bahasa Yunani, yaitu oîkos (oikos) yang berarti "keluarga, rumah tangga" dan vómos (nomos) yang berarti "peraturan, aturan, hukum". Secara garis besar, ekonomi diartikan sebagai "aturan rumah tangga" atau "manajemen rumah tangga." Sementara yang dimaksud dengan ahli ekonomi atau ekonom adalah orang EISSN:2540-8402 | ISSN: 2540-8399 menggunakan konsep ekonomi dan data dalam bekerja. (http://id.wikipedia.org/wiki/Ekonomi. diakses 8 Mei 2012, 20.07 pm)

Menurut M.Akram Kan ekonomi islam adalah "Islamic economics aims the study of he human falah (well-being) achieved by organizing the resources of the earth on the basic of cooperation and participation". Secara lepas dapat diartikan bahwa ilmu ekonomi islam bertujuan untuk melakukan kajian tentang kebahagian hidup manusia yang dicapai dengan mengorganisasikan sumber daya alam atas dasar bekerja sama dan partisipasi. Definisi yang dikemukakan Akram Kan memeberikan dimensi normative (kebahagiaan hidup di dunia dan akhirat) serta dimensi positif (mengorganisasi sumber daya alam). (Nurul Huda dkk. 2007)

Mengenai kaitannya dengan ekonomi dan mu'amalah yaitu dimana kedua kata tersebut erat kaitannya dengan masalah pendistribusian sumberdaya alam khususnya harta sehingga kajian ekonomi islam menjadi bagian dari kajian fiqh mu'amalah. Menurut Muhammad Yusuf Musa berpendapat bahwa kajian fiqh mu'amalah itu mencakup pembahasan tentang ketentuan-ketentuan hukum mengenai kegiatan perekonomian, amanah dalam bentuk titipan dan pinjaman, ikatan 
SIska Lis Sulistiani : Eksistensi Filsafat Hukum Islam..

kekeluargaan, proses penyelesaian perkara lewat pengadilan dan bahkan soal distribusi harta waris.( Dede Rosyada, 1992) Berdasarkan hal tersebut, maka dapat disimpulkan bahwa fiqh mu'amalah adalah mengetahui ketentuan-ketentuan hukum tentang usaha-usaha memperoleh dan memperkembangkan harta, jula beli, hutang piutang, dan jasa penitipan di antara anggota-anggota masyarakat sesuai keperluan mereka, yang difahami dari dalil-dalil syara' yang terinci. (Dede Rosyada, 1992)

\section{Filsafat Hukum Mu'amalah (Ekonomi Islam)}

Filsafat ekonomi, merupakan dasar dari sebuah sistem ekonomi yang dibangun. Berdasarkan filsafat ekonomi yang ada dapat diturunkan tujuan-tujuan yang hendak dicapai, misalnya tujuan kegiatan ekonomi konsumsi, produksi, distribusi, pembangunan ekonomi, kebijakan moneter, kebijakan fiskal, dsb. Filsafat ekonomi Islam didasarkan pada konsep triangle: yakni filsafat Tuhan, manusia dan alam. Kunci filsafat ekonomi Islam terletak pada manusia dengan Tuhan, alam dan manusia lainnya. Dimensi filsafat ekonomi Islam inilah yang membedakan ekonomi Islam dengan sistem ekonomi lainnya kapitalisme dan sosialisme. Filsafat ekonomi yang Islami, memiliki paradigma yang relevan dengan nilai-nilai logis, etis dan estetis yang Islami yang kemudian difungsionalkan ke tengah tingkah laku ekonomi manusia. Dari filsafat ekonomi ini diturunkan juga nilai-nilai instrumental sebagai perangkat peraturan permainan (rule of game) suatu kegiatan(Agustianto, 2011).

Salah satu poin yang menjadi dasar perbedaan antara sistem ekonomi Islam dengan sistem ekonomi lainnya adalah pada falsafahnya, yang terdiri dari nilainilai dan tujuan. Dalam ekonomi Islam, nilai-nilai ekonomi bersumber Al-Quran dan hadits berupa prinsip-prinsip universal. Di saat sistem ekonomi lain hanya terfokus pada hukum dan sebab akibat dari suatu kegiatan ekonomi, Islam lebih jauh membahas nilai-nilai dan etika yang terkandung dalam setiap kegiatan ekonomi tersebut. Nilai-nilai inilah yang selalu mendasari setiap kegiatan ekonomi Islam.

Sistem ekonomi islam sangat berbeda dengan ekonomi kapitalis, sosialis maupun komunis. Ekonomi islam bukan pula berada di tengah-tengah ketiga sistem ekonomi itu. Sangat bertolak belakang dengan kapitalis yang lebih bersifat individual, sosialis yang memberikan hampir semua tanggungjawab kepada warganya serta komunis yang ekstrem, ekonomi Islam menetapkan bentuk perdagangan serta perkhidmatan yang 
Amwaluna, Vol. 2 No.1 (Januari, 2018), Hal 127-144

boleh dan tidak boleh di tujuan,prinsip, asas, kaidah, dan ciri khas transaksikan(http://id.wikipedia.org/wiki/Eko nomi_syariah, 8 Maret 2017. Diakses 20.54 Pm.). Ekonomi dalam Islam harus mampu memberikan kesejahteraan bagi seluruh masyarakat, memberikan rasa adil, kebersamaan dan kekeluargaan serta mampu memberikan kesempatan seluasluasnya kepada setiap pelaku usaha

Dasar syariah membimbing aktivitas ekonomi, sehingga sesuai dengan kaidah-kaidah syariah. Sedangkan akhlak membimbing aktivitas ekonomi manusia agar senantiasa mengedepankan moralitas dan etika untuk mencapai tujuan. Akhlak yang terpancar dari iman akan mebnentuk integritas yang membentuk good corporate governance dan market disiplin yang baik(Agustianto,).

Filsafat hukum fiqh mu'amalah atau falsafah al-tasyri' fi al-mu'amalat istilah sesuatu yang berkaitan dengan hukum islam meliputi tujuan hukum (maqashid), prinsip hukum (mabadi' atau mahiyat), asas hukum atau usus al-hukm, kaidah hukum, dan washatiyyat wal harakiyah fi alhukm(Atang Abd.Hakim, 2011). Sedangkan Hasbi Ash Shiddieqy menambahkan ciri khas, serta watak dan tabi'at yang merupakan landasan pembentukan dan pembinaan hukum islam. Maka berdasarkan hal tersebut dalam makalah ini penulis akan membahas 
SIska Lis Sulistiani : Eksistensi Filsafat Hukum Islam..

kesejahteraan yang berkeadilan, kesejahteraan yang proporsional, yaitu kesejahteraan material dan immaterial(Atang Abd.Hakim). Tujuan ini diupayakan pencapaiannya oleh perbankan syari'ah dengan berpedoman kepada prinsip syari'ah. Hal ini sesuai dengan teori manfaat yang dikembangkan oleh Jeremy Bentham yang mengatakan bahwa manfaat umum adalah asas dalam mencapai kebaikan publik.(atang Abd hakim)

Perwujudan al-hajjat di ranah ekonomi perbankan syari'ah bertujuan memelihara harta agar terjaga kehalalan dan kesucian ( حلال طيبا ) sehingga keturunan terpelihara dari konsumsi barang yang haram.hal ini, karena ragam hajjat di ranah ekonomi perbankan syari'ah merupakan bagian dari prinsip hukum islam bidang mu'amalah (UU No.10 tahun 1998 tentang Perubahan atas UU No.7 Tahun 1992 tentang Perbankan, Pasal 1 ayat (13), yang bertujuan meraih kebaikan dan kemaslahatan masyarakat.

\section{E. Prinsip Hukum Ekonomi Islam}

1) Prinsip aqidah, atau prinsip tauhid. Prinsip ini merupakan fondasi hukum Islam, yang menekankan bahwa:

a) Harta benda yang kita kuasai hanyalah amanah dari Allah sebagai pemilik hakiki. Kitaharus memperolehnya dan mengelolanya EISSN:2540-8402 | ISSN : 2540-8399 dengan baik (al-thayyibat) dalam rangka dan mencari kemanfaatan karunia Allah (ibtigha min fadhillah).

b) Manusia dapat berhubungan langsung dengan Allah. Ekonomi Islam adalah ekonomi yang berdasarkan ketuhanan. Sistem ini bertitik tolak dari Allah, bertujuan akhir kepada Allah, dan menggunakan sarana yang tidak lepas dari syari'at Allah(M. Yusuf Qardhawi, 2010).

2) Prinsip Keadilan, Mencakup seluruh aspek kehidupan, merupakan prinsip yang penting(Sjaichul Hadi Permono, 2010). Sebagaimana Allah memerintahkan adil di antara sesama manusia dalam banyak ayat antara lain.

"Sesungguhnya Allah menyuruh (kamu) berlaku adil dan berbuat kebajikan, memberi kepada kaum kerabat, dan Allah melarang dari perbuatan keji, kemungkaran dan permusuhan. Dia memberi pengajaran kepadamu agar kamu dapat mengambil pelajaran” (Qs.AnNahl: 90)

"Apa saja harta rampasan (fai-i) yang diberikan Allah kepada Rasul-Nya yang berasal dari penduduk kota-kota maka adalah untuk Allah, Rasul, kerabat Rasul, anak-anak yatim, orang-orang miskin dan 
Amwaluna, Vol. 2 No.1 (Januari, 2018), Hal 127-144

orang-orang yang dalam perjalanan, supaya harta itu jangan hanya beredar di antara orang-orang kaya saja di antara kamu. Apa yang diberikan Rasul kepadamu maka terimalah dia. Dan apa yang dilarangnya bagimu maka tinggalkanlah; dan bertakwalah kepada Allah. Sesungguhnya Allah sangat keras hukuman-Nya." (Qs.Al-Hasyr: 9)

3) Prinsip Al-Ihsan (berbuat kebaikan), pemberian manfaat kepada orang lain lebih daripada hak orang lain itu.

4) Prinsip Al-Mas'uliyah (accountabillty), pertanggung jawaban yang meliputi beragam aspek, yakni: pertanggung jawaban anttara individu dengan individu (mas'uliyah alafrad), pertanggung jawaban dalam masyarakat (mas'uliyah almujtama'). Manusia dalam masyarakat diwajibkan melaksanakan kewajibannya demi terciptanya kesejahteraan anggota masyarakat secara keseluruhan serta tanggung jawab pemerintah (mas'uliyah aldaulah) tanggung jawab ini berkaitan dengan baitul mal.

5) Prinsip keseimbangan Prinsip $\mathrm{Al}$ Wasathiyah (al-'itidal, moderat, keseimbangan), syariat islam mengakui hak pribadi dengan batasbatas tertentu. Syari'at menentukan keseimbangan kepentingan individu dan kepentingan masyarakat. Hal ini tampak dari beberapa firman Allah yang artinya:

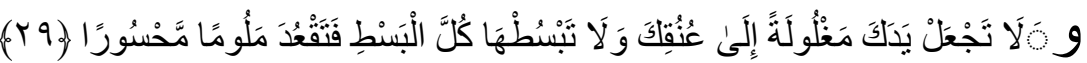

Dan janganlah kamu jadikan tanganmu terbelenggu pada lehermu dan janganlah kamu terlalu mengulurkannya karena itu kamu menjadi tercela dan menyesal (Qs. al-israa: 29)

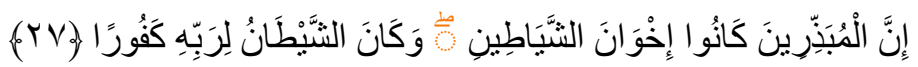

Sesungguhnya pemboros-pemboros itu adalah saudara-saudara syaitan dan syaitan itu adalah sangat ingkar kepada Tuhannya. (Qs.Al-Israa: 27)

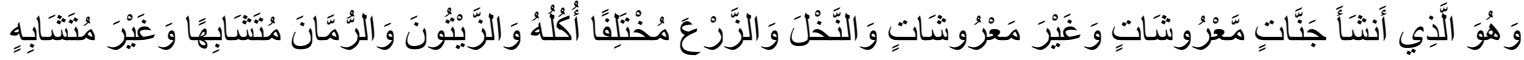

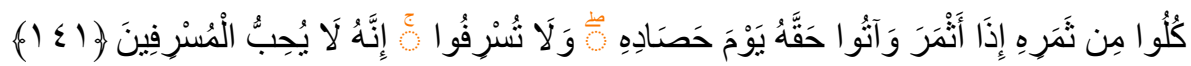

Dan Dialah yang menjadikan kebun-kebun yang berjunjung dan yang tidak berjunjung, pohon kurma, tanam-tanaman yang bermacam-macam buahnya, zaitun dan delima yang serupa (bentuk dan warnanya), dan tidak sama (rasanya). Makanlah dari buahnya (yang bermacam-macam itu) bila dia berbuah, dan tunaikanlah haknya di hari memetik 
Amwaluna, Vol. 2 No.1 (Januari, 2018), Hal 127-144

hasilnya (dengan dikeluarkan zakatnya); dan janganlah kamu berlebih-lebihan. Sesungguhnya Allah tidak menyukai orang-orang yang berlebih-lebihan (Qs.Al-An'am: 141)

6) Prinsip kejujuran dan kebenaran. pentingnya kepentingan bersama Prinsip ini merupakan sendi akhlakul kariimah.

a) Prinsip transaksi yang meragukan dilarang, akad transaksi harus tegas, jelas dan pasti. Baik benda yang menjadi objek akad, maupun harga barang yang diakadkan itu.

b) Prinsip transaksi yang merugikan dilarang. Setiap transaksi yang merugikan diri sendiri maupun pihak kedua dan pihak ketiga dilarang. Sebagaimana sabda rasulullah saw:

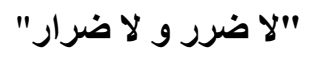

“ Tidak boleh membahayakan (merugikan) diri sendiri dan tidak boleh membahayakan (merugikan) pihak lain." yang harus didahulukan tanpa menyebabkan kerugian individu. Sebagaimana kaidah fiqhiyah: " bila bertentangan antara kemaslahatan sosial dan kemaslahatan individu, maka diutamakan kepentingan kemaslahatan sosial."

d) Prinsip manfaat. Objek transaksi harus memiliki manfaat, transaksi terhadap objek yang tidak bermanfaat menurut syariat dilarang.

e) Prinsip transaksi yang mengandung riba dilarang.

f) Prinsip suka sama suka (saling rela, 'an taradhin). Prinsip ini berlandaskan pada firman Allah Swt:

c) Prinsip mengutamakan kepentingan sosial. Prinsip ini menekankan

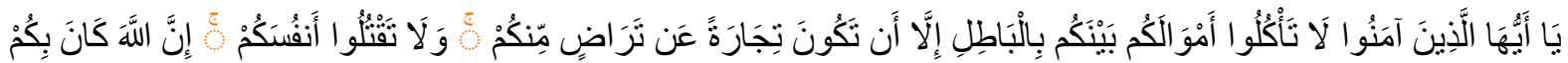

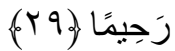

"Hai orang-orang yang beriman, janganlah kamu saling memakan harta sesamamu dengan jalan yang bathil, kecuali dengan jalan perniagaan yang berlaku dengan suka sama-suka di antara kamu.." (Qs.An-Nisa: 29).

Prinsip ini juga berlandaskan hadits nabi : “ tidak lain jual beli harus melalui jalan suka sama suka”. (Hr. Ibnu Majah) g) Prinsip Milkiah, kepemilikan yang jelas. 
h) Prinsip Tiada Paksaan. Setiap orang memiliki kehendak yang bebas dalam menetapkan akad, tanpa tunduk kepada paksaan transaksi apapun, kecuali hal yang diharuskan oleh norma keadilan dan kemaslahatan masyarakat.( Sjaichul Hadi Permono, 2010)

\section{F. Asas Hukum Ekonomi Islam}

1) Tabadul al-manafi (pertukaran manfaat) , kerjasama (musyarakah), dan kepemilikan

Asas pertukaran manfaat (tabadul al-manafi) direduksikan dari Qs.Al-Imran: 191. Ayat ini menerangkan bahwa segala yang diciptakan oleh Allah Swt memiliki nilai kebaikan dan manfaat bagi manusia. Firman Allah adalah aturan dan norma hukum yang bertujuan terciptanya kebaikan (al-mashalih) manusia, dunia dan akhirat. Norma hukum tersebut oleh para ulama diinterpretasi sehingga melahirkan, salah satunya, norma fiqh muamalah. Norma fiqh muamalah sebagai bagian norma hukum islam memiliki tujuan yang sama, yaitu al-mashalih. Al-mashalih dapat diartikan manfaat atau kebaikan ( Sjaichul Hadi Permono, 2010). Yang dimaksudkan untuk dapat mendistribusikan secara merata kepada seluruh manusia, dan seluruh elemen masyarakat, bukan sebuah monopoli demi kepentingan perorangan atau kelompok.

Pertukaran manfaat mengandung pengertian keterlibatan orang banyak, baik secara individual maupun kelembagaan. Oleh karenanya, dalam pertukaran manfaat terkandung norma kerjasama (almusyarakat). Disamping itu, pertukaran manfaat terkait dengan hak milik (haq almilk) seseorang, karena perputaran manfaat hanya dapat terjadi dalam benda yang dimiliki, walaupun sebetulnya hak milik mutlak hanya ada pada Allah Swt, sementara manusia hanya memiliki hak pemanfaatan. Proses pertukaran manfaat melalui norma al-musyarakat dan norma haq-almilk berakhir di norma al-ta'awun (tolong- menolong). Dalam Islam alta'awun hanya terjadi dalam kebaikan dan ketaqwaan (al-khairat atau al-birr wa altaqwa) serta dalam hal yang membawa manfaat bagi semua(Atang Abd.Hakim).

\section{2) Pemerataan kesempatan, 'an} taradhin (suka sama suka atau kerelaan) dan 'adam al-gharar (tidak ada penipuan atau spekulasi)

Asas pemerataan adalah kelanjutan, sekaligus salah satu bentuk penerapan prinsip keadilan dalam teori hukum islam. Pada tataran ekonomi, prinsip ini menempatkan manusia sebagai makhluk 
SIska Lis Sulistiani : Eksistensi Filsafat Hukum Islam..

yang memiliki kesempatan yang sama untuk memiliki, mengelola dan menikmati sumber daya ekonomi sesuai dengan kemampuannya. Disamping itu, asas ini adalah wujud operasional ajaran islam tentang perputaran harta yang tidak boleh hanya berkisar dikalangan orang kaya (alaghnia $)^{1}$, sehingga atas dasar ini hak-hak sosial dirumuskan. Rumusan hak-hak sosial di antaranya ialah teori perpindahan hak milik, sewa menyewa, gadai, pinjammeminjam dan utang piutang. Teori perpindahan hak milik diimplementasikan oleh hukum islam dengan, contoh: jual beli yang bisa berupa akad murobahah, salam atau ishtina', zakat infaq, shadaqah, hibbah, dan waris, sewa menyewa dengan al-isti'arat gadai dengan al-rahn, dan pinjam meminjam dengan al-qardh. Teoriteori ini adalah sarana untuk menciptakan iklim perekonomian yang sehat sehingga lalu lintas perniagaan bisa dirasakan oleh semua lapisan masyarakat secara merata, tanpa adanya monopoli pihak tertentu.

'An taradhin merupakan salah satu asas fiqh mu'amalah. Ia berarti saling merelakan atau suka sama suka. Kerelaan bisa berupa kerelaan melakukan suatu bentuk muamalah, dan atau kerelaan dalam menerima atau menyerahkan harta yang

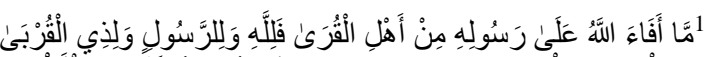

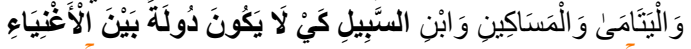

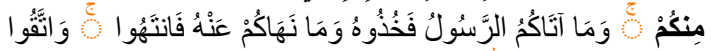

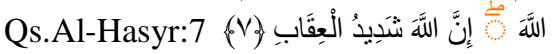

EISSN:2540-8402 | ISSN: 2540-8399
}

menjadi obyek perikatan, serta bentuk muamalah lainnya. Ia adalah salah satu prasyarata keabsahan transaksi bermuamalah di anatara para pihak yang terlibat. Disamping itu, ia merupakan kelanjutan dari azas pemerataan, dan bersinergi dengan asas 'adam al-gharar, arinya prilaku an taradhin memungkinkan tertutupnya sifat-sifat gharar dalam berbagai bentuk transaksi mu'amalah. Hal ini dapat terjadi, karena 'adam al-gharar merupakan kelanjutan dari 'an tharadhin. Al-gaharar ialah sesuatu yang tidak diketahui atau tidak jelas apakah ia ada atau tidak ada. Dalam gaharar ada unsur spekulasi bahkan penipuan yang dapat menghilangkan 'an taradhin. 'adam al-gharar mengandung arti bahwa pada setiap bentuk muamalah tidak boleh ada unsure gharar, yaitu tipu daya atau sesuatu yang menyebabkan salah satu pihak merasa dirugikan oleh pihak lain sehingga menyebabkan hilangnya unsure kerelaan dalam melakukan suatu transaksi.

\section{3) Al-bir wa al-taqwa(Kebaikan dan taqwa)}

Asas al-birr wa al-taqwa merupakan asas yang mewadahi seluruh asas muamalah lainnya. Yaitu segala asas dalam lingkup fiqh mu'amalah dilandasi dan diarahkan untuk al-birr wa al-taqwa. 
Al-birr artinya kebijakan dan berimbang atau proporsional atau berkeadilan.

Hukum islam melalui asas kebaikan dan ketaqwaan menekankan bentuk-bentuk muamalat dalam kategori 'an taradhin, 'adam al-gharar, tabadul almanafi', dan pemerataan adalah dalam rangka pemenuhan dan pelaksanaan saling membantu antara sesama manusia untuk meraih al-birr wa al-taqwa. Islam memberlakukan asas ini dalam semua aturan bermuamalah, termasuk ekonomi perbankan syari'ah, agar dipedomani oleh seluruh umat manusia tanpa melihat latar belakang kelompok dan agama yang dianut. Ia baru diboleh tidak dipedomani hanya untuk memeperlakukan orang kafir yang memerangi, membunuh dan mengusir umat islam dari tempat tinggal mereka(Qs. Al-Mumtahanah: 8-9).

Prinsip hukum islam sebagai asas atau pilar kegiatan usaha dan pedoman perbankan syari'ah dalam mencapai tujuannya itu berkohorensi dengan al-birr wa al-taqwa. Artinya asas-asas hukum islam seperti' an taradhin, tabadul manafi', 'adam al-gharar, ta'awun, al-adl berorientasi kepada pemenuhan al-birr wa al-taqwa.

\section{G. Kaidah Hukum Ekonomi Islam}

Kegiatan ekonomi merupakan salah satu dari aspek muamalah dari sistem Islam, sehingga kaidah fiqh yang digunakan dalam mengidentifikasi transaksi-transaksi ekonomi juga menggunakan kaidah fiqh muamalah. Kaidah fiqh mu'amalah adalah

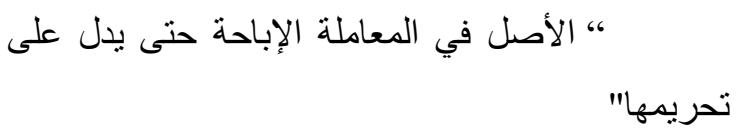

(hukum asal dalam urusan muamalah adalah boleh, kecuali ada dalil yang mengharamkannya).

Ini berarti bahwa semua hal yang berhubungan dengan muamalah yang tidak ada ketentuan baik larangan maupun anjuran yang ada di dalam dalil Islam (AlQur'an maupun Al-Hadist), maka hal tersebut adalah diperbolehkan dalam Islam.

Kaidah fiqh dalam mu'amalah di atas memberikan arti bahwa dalam kegiatan muamalah yang notabene urusan ke-dunia-an, manusia diberikan kebebasan sebebas-bebasnya untuk melakukan apa saja yang bisa memberikan manfaat kepada dirinya sendiri, sesamanya dan lingkungannya, selama hal tersebut tidak ada ketentuan yang melarangnya. Kaidah ini didasarkan pada hadist Rasulullah yang berbunyi: “أنتم أعلم بأمور دنياكم" (kamu lebih tahu atas urusan duniamu). 
SIska Lis Sulistiani : Eksistensi Filsafat Hukum Islam..

Bahwa dalam urusan kehidupan dunia yang penuh dengan perubahan atas ruang dan waktu, Islam memberikan kebebasan mutlak kepada manusia untuk menentukan jalan hidupnya, tanpa memberikan aturan-aturan kaku yang bersifat dogmatis. Hal ini memberikan dampak bahwa Islam menjunjung tinggi asas kreativitas pada umatnya untuk bisa mengembangkan potensinya dalam mengelola kehidupan ini, khususnya berkenaan dengan fungsi manusia sebagai khalifatul-Lilah fil 'ardlh (wakil Allah di bumi).

Efek yang timbul dari kaidah fiqh mu'amalah di atas adalah adanya ruang lingkup yang sangat luas dalam penetapan hukum-hukum mu'amalah, termasuk juga hukum ekonomi. Ini berarti suatu transaksi baru yang muncul dalam fenomena kontemporer yang dalam sejarah Islam belum ada/dikenal, maka transaksi tersebut "dianggap" diperbolehkan, selama transaksi tersebut tidak melanggar prinsipprinsip yang dilarang dalam Islam. Sedangkan transaksi-transaksi yang dilarang dalam Islam adalah transaksi yang disebabkan oleh faktor:

\section{- Haram zatnya}

Di dalam fiqh mu'amalah, terdapat aturan yang jelas dan tegas mengenai obyek transaksi yang diharamkan, seperti EISSN:2540-8402 | ISSN : 2540-8399 minuman keras, daging babi, dan sebagainya. Oleh karena itu melakukan transaksi yang berhubungan dengan obyek yang diharamkan tersebut juga diharamkan. Hal ini sesuai dengan kaidah fiqh:

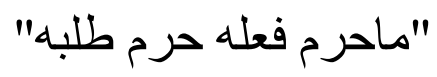

(setiap apa yang diharamkan atas obyeknya, maka diharamkan pula atas usaha dalam mendapatkannya).

Kaidah ini juga memberikan dampak bahwa setiap obyek haram yang didapatkan dengan cara yang baik/halal, maka tidak akan merubah obyek haram tersebut menjadi halal.

\section{- Haram selain zatnya}

Beberapa transaksi yang dilarang dalam Islam yang disebabkan oleh cara bertransaksi-nya yang tidak sesuai dengan prinsip-prinsip muamalah, yaitu: tadlis (penipuan), ikhtikar (rekayasa pasar dalam supply), bai' najasy (rekayasa pasar dalam demand), taghrir (ketidakpastian), dan riba (tambahan).

- Tidak sah

Segala macam transaksi yang tidak sah/lengkap akadnya, maka transaksi itu dilarang dalam Islam. Ketidaksah/lengkapan suatu transaksi bisa disebabkan oleh: rukun (terdiri dari pelaku, 
objek, dan ijab kabul) dan syaratnya tidak terpenuhi, terjadi ta'alluq (dua akad yang saling berkaitan), atau terjadi two in one (dua akad sekaligus). Ta'alluq terjadi bila kita dihadapkan pada dua akad yang saling dikaitkan, di mana berlakunya akad pertama tergantung pada akad kedua. Yang seperti ini, terjadi bila suatu transaksi diwadahi oleh dua akad sekaligus sehingga terjadi ketidakpastian (grarar) akad mana yang harus digunakan.maka transaksi ini dianggap tidak sah.

\section{H. Ciri Khas Hukum Ekonomi}

\section{Islam}

Sebagai bagian dari hukum islam, fiqh mu'amalah memiliki ciri khas seperti yang dimiliki hukum islam, yaitu kemanusiaan (insaniyah), berakhlak (akhlaqii) dan universal ('aalamii).

1) Kemanusiaan (insaniyah) artinya bahwa hukum yang diletakkan oleh islam adalah untuk kebahagiaan manusia duniadan akhirat. Hukum islam adalah hukum yang dengan seksama memberikan perhatian yang penuh kepada manusia,baik mengenai diri, ruh, akal, usaha/pekerjaan, hubungan antara sesama, ekonomi politik dan yang lainnya, maupun pahala dan siksa. Oleh karenanya ia menjadikan manusia sebagai sumber dari segala sumber hukum dan sekaligus menjadikannya sebagai subyek dan obyek hukum.

2) Akhlaqy, artinya hukum islam itu sarat dengan nuansa akhlaq, etika dan moral. Kata “ al-akhlaq" adalah plural dari kata khilq atau khuluq yang berarti al-sajiyat (perangai atau budi pekerti), al-thabi'at (watak dasar, kelakuan ), al-'adat (kebiasaan. Secara istilah, al-akhlaq ialah sifat yang tertanam dalam jiwa yang mendorong untuk melakukan perbuatan tanpa memerlukan pemikiran dan pertimbangan, pengertian ini sejalan dengan yang ditawarkan oleh Imam al-Ghazali dan Ibrahim Anis

3) Ciri khas ketiga ialah universal artinya bahwa hukum islam bersifat dan berlaku umum. Pemberlakuan UU secara umum dan menyeluruh bagi masyarakat diperlihatkan dalam aturan tentang pendiriandan kepemilikan bank syariah. Ia tidak hanya diperuntukan bagi warga Negara Indonesia atau Badan hukum Indonesia, tetapi juga bagi warga negara asing atau badan hukum asing. Dari sini tampak bahwa UU tidak membatasi dirinya dengan sekat-sekat agama, warga Negara, dan tempat tinggal meskipun dari 
SIska Lis Sulistiani : Eksistensi Filsafat Hukum Islam..

sudut nama, bank Syariah bercirikan Islam.

\section{SIMPULAN}

Dari berbagai penjelasan di atas, maka dapat ditarik sebuah kesimpulan bahwa fiqh mu'amalah merupakan ilmu yang mempelajari segala prilaku manusia dalam memenuhi kebutuhan hidupnya dengan tujuan memperoleh kedamaian dan kesejahteraan dunia akhirat. Perilaku manusia di sini berkaitan dengan landasan-landasan syariah sebagai rujukan berprilaku dan kecenderungankecenderungan dari fitrah manusia. Kedua hal tersebut berinteraksi dengan porsinya masing-masing sehingga terbentuk sebuah mekanisme ekonomi (muamalah) yang khas dengan dasar-dasar nilai ilahiyah. Filsafat hukum fiqh mu'amalah atau falsafah al-tasyri' fi al mu'amalat istilah sesuatu yang berkaitan dengan hukum islam meliputi tujuan hukum (maqashid), prinsip hukum (mabadi' atau mahiyat), asas hukum atau usus al-hukm, kaidah hukum, dan washatiyyat wal harakiyah fi alhukm.

Saran yang ingin disampaikan penulis dalam makalah ini khususnya untuk praktisi ekonomi Islam dapat mengimplementasikan nilai-nilai ilahiah yang terkandung dalam setiap aspek transaksi ekonomi agar tercapai maslahah untuk semua pihak.

\section{DAFTAR PUSTAKA}

\section{Al-Quran Alkariim}

Agustianto .Filsafat Ekonomi Islam. 2011. http://shariaeconomics.wordpress. com/2011/02/21/58/. Diakses

11.43.rabu 14 maret 2012

Ahmad, Hanafi. Pengantar Filsafat Islam., ed. 19, Jakarta: PT Bulan Bintang 1996.

Ali, Zainuddin, Filsafat Hukum, Jakarta: Sinar Grafindo, 2006.

Anshari, Endang Saiffudin, Ilmu Filsafat dan Agama, Surabaya: PT.Bina Ilmu, 1981.

Clement, C.J. Webb, A history of philosophy, London: Oxford University Press, 1949.

Hakim, Atang Abd. Fiqh Perbankan Syari'ah. Bandung; Refika Aditama. 2011

Huda, Nurul dkk. Ekonomi Makro Islam Pendekatan Teoretis. Jakarta: Kencana. 2007. Liang, Gie. Pengantar Filsafat Ilmu Jogjakarta : Leberty. Nasution, Hasyimsyah, Filsafat Islam, Jakarta : Gaya Media Pratama, 2002. 
Amwaluna, Vol. 2 No.1 (Januari, 2018), Hal 127-144

Rosyada, Dede, Hukum islam dan Pranata

Sosial, Jakarta: Rajawali Press, 1992.

Shomad, Abd. Hukum Islam. Jakarta:

Kencana. 2010.

Syarifuddin, Amir.Ushul Fiqh Jilid 1.

Jakarta: Kencana. 2011.

UU No.10 tahun 1998 tentang Perubahan atas UU No.7 Tahun 1992 tentang Perbankan, Pasal 1 ayat (13)
Permono, Sjaichul Hadi, Formula Zakat, Menuju Kesejahteraan Sosial. Surabaya: Aulioa.2008.

Qardhawi, M. Yusuf. Norma dan Etika Ekonomi Islam, Jakarta: Gema Insani Press, 1987.

http://id.wikipedia.org/wiki/Filsafat http://id.wikipedia.org/wiki/Ekonomi. 